\title{
LINEARIZATION OF OBJECT MODEL WITH VECTOR CONTROL
}

\author{
Kulanina Y. V. - PhD, Senior lecturer of the Electrical Machines Department, Zaporizhzhia National Technical University, \\ Ukraine. \\ Yarymbash D. S. - Dr. Sc., Associate Professor, Head of the Electrical Machines Department, Zaporizhzhia National Technical \\ University, Ukraine. \\ Kotsur M. I. - PhD, Associate Professor, Electrical and Electronic Apparatuses Department, Zaporizhzhia National Technical \\ University, Ukraine. \\ Yarymbash S. T. - PhD, Associate Professor, Electrical Machines Department, Zaporizhzhia National Technical University, \\ Ukraine.
}

\begin{abstract}
Context. A sufficient number of ways to implement vector control algorithms are very complex and in most cases tend to mismatch the vector of the resulting parameters of the control object. Therefore, there is a need to simplify complex non-linear vector control systems and apply linear dynamic models of a non-linear object with vector control for them. Currently, for a complex vector control system, there are no sufficiently accurate equivalent simple models. Development of reliable simple dynamic models will allow to design a vector control system with maximum use of linear methods of synthesis and analysis.

Objective. The goal of the paper is development of linear dynamic model of a non-linear object with vector control, which reproduces its dynamics accurately enough for practice.

Method. The following methods were used to solve the problems posed: the state space method for describing the operation of control systems; filtering theory, in particular, observers for estimation state vectors, uncertainties, and parameter identification; modal control methods for the synthesis of observers and regulators; numerical simulation method to illustrate the performance of synthesized control systems; vector control of a nonlinear object.

Results. For the investigated robust vector control system of the object with a substantial non-linearity of properties and characteristics, simple linear equivalent mathematical models were compiled, rather accurately reproducing the operation of the original system in all modes of operation. Simplification of mathematical models is achieved by considering the dynamics of the entire system in a synchronous basis, robust methods for controlling parameters, and by neglecting really small errors in the work of regulators and observers. The synthesized models, as well as the original nonlinear system, have the property of robustness due to the use of combined control.

Conclusions. The simplicity and linearity of the equivalent system allows us to synthesize the control laws of the original nonlinear system by well-developed linear methods with significantly less time spent on modeling. Numerical simulation of the dynamics of the original nonlinear and equivalent linear systems showed a good agreement between transient and stationary processes.
\end{abstract}

KEYWORDS: model, linearity, control, observer, robustness.

\author{
ABBREVIATIONS \\ $\mathrm{IM}$ is an Induction Motor; \\ VCis a Vector Control; \\ HACS is High-tech Automated Control System; \\ EMD is an Electric Motor Device; \\ $\mathrm{CD}$ is a Converting Device; \\ ACS is an Automatic Control System; \\ EM is an Executive Device; \\ $\mathrm{CO}$ is a control object; \\ TS is a Technological System; \\ PSS is a Power Supply System; \\ $\mathrm{S}$ is a Source; \\ ES is an Elastic System; \\ $\mathrm{FC}$ is a Frequency Converter; \\ PWM is a Pulse-Width Modulation; \\ CTC is a Combined Torque Controller; \\ $\mathrm{CCC}$ is a Combined Current Controller.
}

\section{NOMENCLATURE}

$i_{\alpha \beta}$ is a vector of parameters of currents reduced to basis $(\alpha, \beta)$; $u_{\alpha \beta}$ is a vector of parameters of volteges reduced to basis $(\alpha, \beta)$;

$i_{p}$ is a program value of the current parameter;

$\left\langle{ }^{\wedge}\right\rangle$ is a symbol for evaluating the corresponding variables,

$\omega_{0}$ is a parameter of the vector velocity flux linkage $\psi$ in the bases $(\alpha, \beta)$;

$\vartheta$ is a rotation angle of the working body of the control object;

$\omega$ is a speed parameter;

$\omega_{p}$ is a program speed parameter;

$m_{0}$ is a desired parameter of the electromagnetic moment of the control object;

$m$ is a parameter of the electromagnetic moment of the control object;

$m_{p}$ is a program parameter of the electromagnetic moment of the control object;

$\vec{i}_{d q p}$ is a vector of the program current parameters written in synchronous basis $(d, q)$; 
$\vec{u}_{d q p}$ is a vectors of the program voltage parameters written in the synchronous basis $(d, q)$;

$u_{p}$ is a programmatic signal corresponding to the desired input parameters voltage of the control object;

$u$ is a voltage parameter of the control object;

$m_{l}$ is a load moment parameter of the control object;

$m_{f}$ is a parameter of the friction point of the control object;

$I$ is a parameter of the rotor inertia moment of the control object;

$\psi_{d}$ is a parameter of the vector flux module of the control object;

$n$ is a constructive parameter of the number pairs poles of the management object;

$L_{s}$ is a stator inductance parameters of the control object;

$L_{r}$ is a rotor inductance parameters of the control object;

$L_{m}$ is a parameters of the mutual inductance of the stator and the rotor of the control object;

$T_{r}$ is a rotor time constant parameter of the control object;

$R_{s}$ is a parameter of stator resistance of the control object;

$R_{r}$ is a parameter of rotor resistance of the control object;

$R_{s 0}$ is a parameter of the nominal value stator resistance of the control object;

$R_{r 0}$ is a parameter of the nominal value rotor resistance of the control object;

$\vartheta$ is a parameter of the rotor movement of the control object;

$\vartheta_{p}$ is a program parameter of the rotor movement of the control object;

$I_{0}$ is a deterministic part of the current parameter of the control object;

$m_{0}$ is a deterministic part of the electric moment parameter of the control object;

$L_{m 0}$ is a deterministic part of the mutual inductance parameter of the control object;

$L_{r 0}$ is a deterministic part of the rotor inductance parameter of the control object;

$J_{\delta}$ is an unknown error of the moment inertia value of the control object;

$m_{\delta}$ is an unknown error of the electric moment value of the control object;

$L_{m \delta}$ is an unknown error of the mutual inductance value of the control object;

$L_{r \delta}$ is an unknown error of the rotor inductance value of the control object;

$\sigma$ is a scattering coefficient;

$p$ is a differentiation operator (subscript $\mathrm{p}$ indicates program value);

$k_{1}$ is a transmission coefficient of FC wich taking into account changes in voltage parameters;

$R_{s \delta}$ is a value error of the parameter stator resistance of the control object;

$k_{1 \delta}$ is a transfer coefficient error;
$L_{s \delta}$ is a value error of the stator inductance parameter of the control object;

$\vec{q}$ is a vector of constant coefficients;

$\hat{\psi}$ is an estimation of the rotor flux vector of the control object;

$\hat{\psi}^{*}$ is an estimation of the program rotor flux vector of the control object;

$e_{\alpha \beta}$ is a projection EMF of the control object;

$e_{0}$ is a nominal value of the stator EMF vector of the control object;

$\hat{e}_{\delta}$ is an error estimation of the stator emf vector of the control object;

$\vec{l}$ is a vector of constant transmission coefficients of the observer, defining its characteristics;

$\omega_{s l}$ is a sliding of the control object;

$\alpha$ is a temperature coefficient of the control object.

\section{INTRODUCTION}

The problem of control uncertain objects is one of the most common tasks of the control theory. A special place in the class of controlled systems is occupied by objects, the dynamic processes in which are described by nonlinear differential equations. Due to the large variety of nonlinear functions, included in the mathematical models of such objects, individual approaches are used in the design of control systems.

For the most part, approaches and methods based on the direct Lyapunov method [1], the differentialgeometric theory of differential equations [2-4] and the theory of constructing equivalent mathematical models are used to solve this problem, which makes it possible to transform the output nonlinear equations into simpler and sometimes even in linear [5]. This makes it possible to simplify the processes of analysis and synthesis of control systems, as well as to apply previously developed design methods. It is advisable to develop such models on the most complex non-linear objects of control, for example, IM $[6,7]$. IM is the most common type of electric motors. Its application is most widely used in the control systems of elevators, industrial machines, machine tools, cranes, escalators, locomotives, etc. IM differs from other types of engines with ease of maintenance, low cost, high reliability, the ability to work in aggressive environments $[6,7]$. IM, due to their complex dynamics, was originally intended for unregulated control. The development of electric power transformer and computer technology has created the prerequisites for the development of IM control systems, which potentially will not be yield to DC motors in terms of quality control. The behavior of IM is by nature very nonlinear [8], therefore, in order to ensure a high ratio of productivity and cost, it is necessary to develop advanced control methods [9]. New principles of control of IM, as an executive body, consider electromagnetic processes not in the traditional coordinate system, but in that which is associated with any physical 
vector. Therefore, the principle of control is called "vector control" [10]. This control method allows using IM to obtain the same quality indices as DC motors.

Achieved accuracy and dynamic characteristics of modern IM are provided due to complex nonlinear control algorithms, which complicates the control of complex objects. Under complex objects, for example, are understood mechanical systems consisting of solids with unknown mass-inertial characteristics, interconnected by elastic bonds, prone to external unknown effects [11]. Such systems may include antenna control systems for radars, metalworking machines, sighting systems for small arms, mounted on moving objects, etc.

The development of complex object control systems is complicated by the interaction of two complex dynamic processes occurring in an object with $\mathrm{VC}$ and in a technological object. This complexity, first of all, is due to numerous nonlinearities in the mathematical model of the control object on the basis of VC. Therefore, the issue of developing simplified models of nonlinear objects, in particular IM, is an actual issue.

The object of study is the process of vector control of an object with complex nonlinear interconnections of parameters and characteristics.

The subject of study is a model of a non-linear object with vector control.

The purpose of the work is to develop a linear dynamic model of a non-linear object with vector control, which reproduces its dynamics with an accuracy sufficient for practice.

\section{PROBLEM STATEMENT}

Generalized HACS is a complex set of structural nonlinear elements: EMD, CD, ACS, ED, CO. HACS is intended to bring the working body of TS into motion and control this movement according to the prescribed law. Improving the quality and production of technological equipment is associated with the prevailing development and improvement of HACS and its controlnsystem [12]. At the same time, the properties of HACS (Fig. 1) are determined by the interrelated characteristics of the elements that form its subsystems (mechanical, electrical and magnetic) [13].

PSS includes the following derivative elements: power source, regulating and matching devices, rechargeable batteries or other alternative sources. The choice of $S$ is carried out depending on the purpose of HACS in general, solved tasks in the technological process of automated production, the feasibility study of the choice of the $\mathrm{S}$ type at the stage of the technical proposal during designig of HACS.

CD serves for converting electric current and voltage: alternating current into a constant, direct current into alternating; alternating current of one frequency in alternating current of another frequency; low constant voltage to high constant voltage.

CKulanina Y. V., Yarymbash D. S., Kotsur M. I., Yarymbash S. T., 2019 DOI 10.15588/1607-3274-2019-2-20

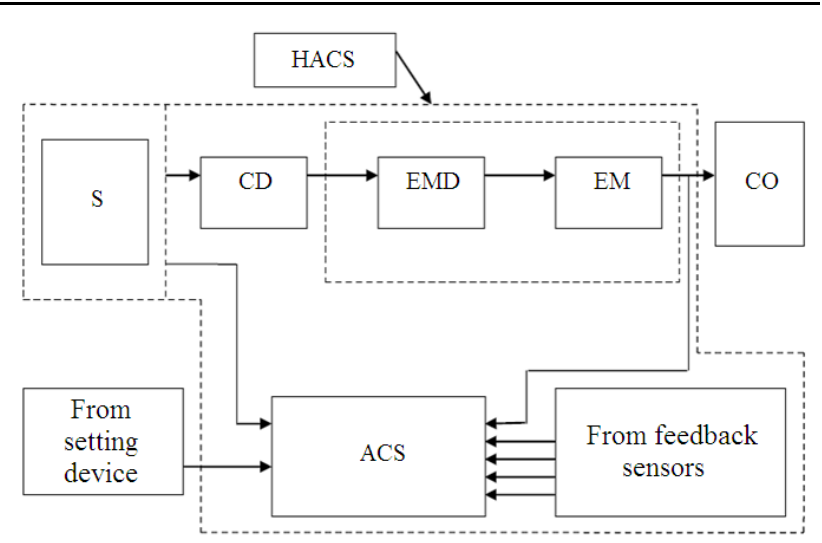

Figure 1 - Generalized functional scheme of HACS construction

EMD serves to convert electrical energy into mechanical to influence the CO. In other words, the EMD must develop a driving force: a driving moment or a mechanical effort transmitted to the $\mathrm{S}$, that is, to perform the functions of the ED for the movement of the working body in accordance with the prescribed law of control.

Under OC it is necessary to understand the unit of technological equipment, as a result of which the shape of the initial workpiece changes, its position or physical properties. In the automated production, complex technological complexes are used to provide processing of the workpiece, dimensional control, transportation and storage of the product. This can involve various machines, automatic tool changers and products, automatic drives and specialized manipulation systems (including industrial robots). Each OC, in its turn, is a constructive module that provides the possibility of a necessary coordinate movement (for example, a cutting tool) with respect to the product being manufactured in ES of OC. Under ES of OC means a set of all nodes and mechanisms that make up the casing of the fixed part (carrier system) and EM drives. Executive mechanisms directly provide relative movements of working bodies, and their dynamic properties significantly affect the output characteristics of the HACS.

The generalized structure of HACS (Fig. 1) is the basis for developing a linear dynamic model of an object with vector control. In this case, it is necessary to take into account the limitations imposed by EM and OC parameters on the operation of HACS and energy and technology parameters of OC.

\section{REVIEW OF THE LITERATURE}

In $[14,15]$, the general theoretical solution of $\mathrm{VC}$ algorithm synthesis by the moment and the flux parameter of IM is presented with an indirect orientation along the vector of the stator flux parameter of the stator, which guarantees global asymptotic testing of the moment parameter and the flux parameter of the stator IM. The control obtained on the basis of the principle of passivity is open with respect to the coordinates of the magnetic subsystem of the object determines its high sensitivity to parametric perturbations. 
In [16,17], a criterion was proposed for maximizing the ratio of control parameters of current and moment of IM based on a mathematical model of the control object, which takes into account the nonlinearity properties of IM. Using of this criterion in vector control algorithms made it possible to ensure asymptotic testing of specified trajectories of current parameter changes with maximization of the ratio of current and moment parameters, regardless of the location of the operating point of the function, which reflects the nonlinearity of IM parameters.

The well-known algorithm of indirect vector control with orientation on the rotor flux linkage vector [18-19] is based on the standard mathematical model of IM. This algorithm provides an asymptotic orientation along the vector of the rotor flux linkage parameter, and also guarantees the asymptotic refinement of a given trajectory of the torque parameter of the control object. For the operation of the algorithm, the necessary condition is to measure the output variables of IM, namely the parameters of the stator currents and the angular velocity of the rotor.

The well-known algorithm vector control of IM moment based on the concept of dynamic linearization of feedback on the measured output in the conditions of direct (based on observers) field orientation [20-24]. This algorithm provides asymptotic testing of specified trajectories of IM moment parameter while maximizing the relationship between the torque parameters and IM current, improves efficiency and reduces losses in the control object.

There is an algorithm for frequency control of the torque parameter of the control object of IM [25-27]. The control quality indicators of this algorithm are somewhat worse than in the previous two [25-27]. A sufficient number of ways to implement vector control algorithms are very complex and in most cases tend to mismatch the vector of the resulting parameters of the control object. Therefore, there is a need to simplify complex non-linear vector control systems and apply linear dynamic models of a non-linear object with vector control for them. Currently, for a complex vector control system, there are no sufficiently accurate equivalent simple models. Development of reliable simple dynamic models will allow to design a vector control system with maximum use of linear methods of synthesis and analysis.

\section{MATERIALS AND METHODS}

The basis is a generalized functional scheme of vector control, which is shown in Fig. 2.

Simplification of the scheme occurs due to the following blocks:

«Optimizer» is a shaper of optimal program parameters, minimizes the resulting parameter of the economy of the control object. The regulator is also built on the combined principle and consists of an observer of uncertainty and the laws of the formation of the transient characteristics of the parameters of the control object.

CKulanina Y. V., Yarymbash D. S., Kotsur M. I., Yarymbash S. T., 2019 DOI 10.15588/1607-3274-2019-2-20

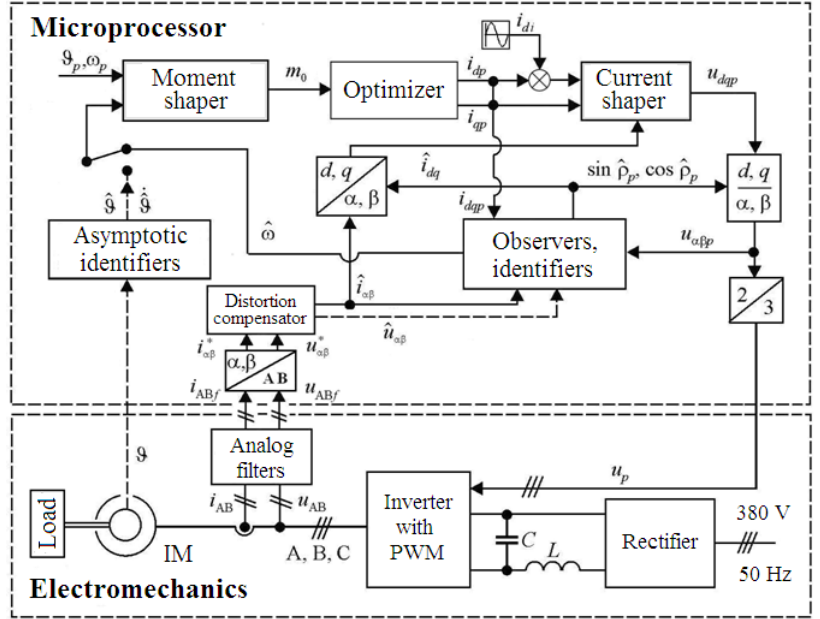

Figure 2 - Functional scheme of the object with vector control

"Observers, identifiers" is the most complex and computationally voluminous block of the control system. In this block variables are calculated, which largely determine the properties and quality indicators of the control system.

The equations of motion of the rotor and the formation of the parameter of the electromagnetic moment $m$ [11] are considered.

$$
\begin{gathered}
I \ddot{\vartheta}=m+m_{l}+m_{f}, \\
m=n \frac{L_{m}}{L_{r}} \psi_{d} i_{q}, \\
T_{r} \dot{\psi}_{d}+\psi_{d}=L_{m} i_{d} .
\end{gathered}
$$

In equation (1), $m, m_{f}, m_{l}$ and $I \ddot{\vartheta}$ are non-linear (in the case when $I$ is an unknown and variable reduced parameter of the inertia moment).

From the expression (2) it can be seen that the same parameter of the electromagnetic moment can be created with a multitude of combinations $\psi_{d}$ and $i_{q}$ that can cause the appearance of different values of the energy efficiency parameter. Among these combinations is the combination with the minimum value that should be used. In the well-known $\mathrm{VC}$ of IM schemes, automatic minimization of the energy efficiency parameter is not carried out, but constant adjustment is made to the most probable load parameter.

As can be seen from expressions (2) and (3), the accuracy of the calculation $m$ depends on the accuracy of knowledge of $L_{m}, L_{r}$ and $T_{r}$. Since the inaccurately calculated value $m$ is fed to the input of the torque parameter controller, the program parameter of the current $i_{q p}$, and, consequently, the parameter of the electromagnetic moment are formed with an error.

Note. PI-controller, that used in known systems, is able to compensate for only the constant components of the disturbances $m_{f}, m_{l}$ included in equations (1). PI-controller is completely unable to compensate for errors in control, 
which arise due to inaccuracies in the knowledge of the inertia moment parameter, and variable disturbances. Moreover, in case of positional control with PI-controller, the deviation of the inertia moment parameter from its calculated value can lead to instability of motion.

It should be noted that, in the general case, all the parameters and effects on the rotor control object which entering into equations (1)-(3) are unknown. Below it is shown how, under the conditions of the specified uncertainty, it is possible to ensure high accuracy, preset indicators of the quality of transient processes and a minimum of the energy efficiency parameter.

According to [11], to compensate for the influence of uncertainties, it is assumed that $m_{l}, m_{f}, T_{r}$ are unknown, and the parameters of the system are not precisely known, and

$$
\begin{aligned}
& I=I_{0}+I_{\delta}, m=m_{0}+m_{\delta}, \\
& L_{m}=L_{m 0}+L_{m \delta}, L_{r}=L_{r 0}+L_{r \delta}
\end{aligned}
$$

For $L_{m 0}, L_{r 0}$, the values of the inductance parameter on the linear part of the nonlinear function are taken as nominal values. According to (2), (3) can be written

$$
m=n L_{m} L_{r}^{-1}\left(L_{m} i_{d}-T_{r} \dot{\psi}_{d}\right) i_{q} .
$$

A serious problem standing in the way of system optimization in dynamic modes is the large unknown time constant $T_{r}$ in (3) and (5). For the purpose of compensation, as well as compensation for the influence of uncertainties, the nominal electromagnetic moment is taken as a parameter

$$
m_{0}=n L_{m 0}^{2} L_{r 0}^{-1} i_{d} i_{q} .
$$

In this case, taking into account (4)-(6), equation (1) can be given the form

$$
I_{0} \ddot{\vartheta}=m_{0}+f_{m},
$$

where the uncertainty is

$$
f_{m}=m_{\delta}+m_{l}+m_{f}-I_{\delta} \ddot{\vartheta}+f_{1}\left(L_{m \delta}, L_{r \delta}, T_{r} \dot{\psi}_{d}, i_{d}, i_{q}\right) .
$$

Equation (7) is an equation of a fully deterministic object with nominal parameters, subject to the total uncertainty $f_{m}$. The task of ensuring the robustness and accuracy of the equation is to estimate the uncertainty of $f_{m}$ and its compensation at the expense of a special addend in the control law. Uncertainty estimated by observer

$$
\dot{z}=-k\left(z+m_{0}+k I_{0} \dot{\vartheta}\right), \hat{f}_{m}=z+k I_{0} \dot{\vartheta} .
$$

To compensate for the effect of uncertainty, a combined control law is specified in

$$
m_{0}=m_{00}-\hat{f}_{m} .
$$

Substitution (10) in (7) gives

$$
I_{0} \ddot{\vartheta}=m_{00}+f_{m}-\hat{f}_{m} .
$$

With a sufficiently accurate estimate $\hat{f}$ of the uncertainty $f$, instead of equation (11), we can assume

$$
I_{0} \ddot{\vartheta}=m_{00} \text {. }
$$

The law of positional control is given in the form

$$
m_{00}=-k_{0}\left(\vartheta-\vartheta_{p}\right)-k_{1}\left(\dot{\vartheta}-\dot{\vartheta}_{p}\right)+I_{0} \ddot{\vartheta}_{p} .
$$

When controlling only speed, the following control law is adopted:

$$
m_{00}=-k_{0}\left(\omega-\omega_{p}\right)-k_{1} \int\left(\omega-\omega_{p}\right) d t+I_{0} \dot{\omega}_{p},
$$

where $\omega=\dot{\vartheta}$ and $\omega_{p}=\dot{\vartheta}_{p}$.

The integral part in the regulator (14) is intended only for the formation of a given type of transient characteristic. Astatism of the system is provided by the compensating part $\hat{f}_{m}$ in the control law (10)

When working with the limiting parameter of the stator current of the control object, a simplified control law is recommended to avoid overshooting.

$$
m_{00}=-k_{0}\left(\omega-\omega_{p}\right)+I_{0} \dot{\omega}_{p}
$$

By determining the coefficients $k_{0}, k_{1}$, you can set the necessary indicators of the transients quality.

From (6)-(8), (10), (12) it follows that the electromagnetic moment parameter is robust to all parameters included in (8), as well as to a change in the parameter of the rotor flux module. With an accurate assessment of variables and accurate formation of stator currents in accordance with their program values $\left(i_{d}=i_{d p}, i_{q}=i_{q p}\right)$ and in case of failure to achieve current and voltage parameters and their limitations, the system will behave as linear with given transient quality indicators regardless of disturbances and spread of electric drive parameters.

By minimizing the energy efficiency parameter, the following expressions were found for the optimal (program) parameter values of the components of the stator current vector $[9,10]$ :

$$
\begin{aligned}
& i_{d p}=\sqrt[4]{\frac{R_{S}+R_{r} L_{m r}^{2}}{R_{s}}} \sqrt{\frac{\left|m_{0}\right|}{n L_{m 0}}}, \\
& i_{q p}=\sqrt[4]{\frac{R_{S}}{R_{s}+R_{r} L_{m r}^{2}}} \sqrt{\frac{\left|m_{0}\right|}{n L_{m 0}}} \operatorname{sign} m_{0},
\end{aligned}
$$

The parameters $R_{s}$ i $R_{r}$, which are in (15), due to the temperature change can vary in wide limits. At the time when the time comes for changes in temperature and static resistance, proportions must be taken into account. Therefore, instead of the expression (15) you can imagine 


$$
\begin{gathered}
i_{d p}=\sqrt[4]{\frac{R_{s 0}+R_{r 0} L_{m r}^{2}}{R_{s 0}}} \sqrt{\frac{\left|m_{0}\right|}{n L_{m 0}}}, \\
i_{q p}=\sqrt[4]{\frac{R_{s 0}}{R_{s 0}+R_{r 0} L_{m r}^{2}}} \sqrt{\frac{\left|m_{0}\right|}{n L_{m 0}}} \operatorname{sign} m_{0} .
\end{gathered}
$$

The optimality of the program values of the stator currents parameters is preserved with all the variations of other parameters. At the same time, the ratio between program currents is remarkable in simplicity:

$$
\frac{i_{d p}}{i_{q p}}=\sqrt{1+L_{m r}^{2} \frac{R_{r 0}}{R_{s 0}}} \operatorname{sign} m_{0},
$$

from which it follows $\left|i_{d p} i_{q p}^{-1}\right|=$ const. The value of the program parameter of the magnetizing current $i_{d p}$ is determined by the first expression in (24). Then the program parameter of the torque current $i_{q p}$ from the relation (6) is determined by the expression

$$
i_{q p}=\frac{m_{0} L_{r 0}}{n L_{m 0}^{2} i_{d p}} .
$$

Expressions (16), (18) are generally non-linear. For linearization, one has to optimize the energy efficiency parameter for one most typical case $m_{0}$ (this is done in all known vector control systems). In this case $i_{d p}$ will be constant, and $i_{d p}$ according to (18) it will have only one variable $m_{0}$, on which it will depend linearly.

Fig. 3 shows a block diagram of an electromagnetic torque parameter controller and a shaper for program parameters of stator currents using a combined torque parameter controller.

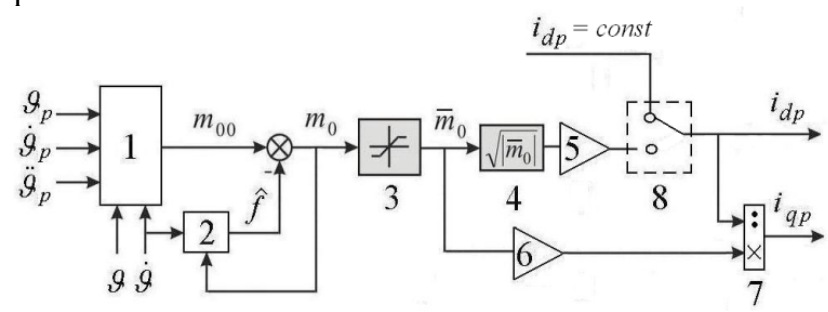

Figure 3 - The block diagram of the parameter regulator of the electromagnetic moment and the program parameters shaper of the stator currents:

1 - block forming the type of transient response $m_{00}(14), 2$ block forming the uncertainty observer $\hat{f}_{m}(9), 3$ - block limiting the value of the parameter of the electromagnetic moment $m_{0}$, 4block extracting the square root, 5 - block forming the optimal program parameter of the magnetizing current (16), 6 - block forming of the numerator of expression (25), 7 - block forming of the program parameter of the torque current (18), 8 - block of switching according to the optimal parameter of magnetization to a predetermined program parameter of magnetization
The upper key position is intended for operation in modes with fast and frequent changes in the rotor speed (with the key in the upper position, the program current is set constant). Blocks 1-2 serve to provide robustness, and blocks 3-7 are designed to minimize the energy efficiency parameter. Blok 8 switches the modes described above. Since the block 7 is non-linear when $i_{d p}$ is changed, to eliminate non-linearity, we will consider the case when $i_{d p}=$ const.

One of the main components of the described system and all known systems VC of IM is the chain of formation of program voltage parameters. The study of VC IM showed that in the dynamics of the system can distinguish slow and fast processes. Slow processes take place in control loops for speed, flow coupling, parameter identification, and engine speed estimation. Loops of control current parameters have fast dynamics. This gives grounds to investigate the contours of the currents, regardless of slow processes. A lot of works have been devoted to the design of current circuit regulators in IM. Currently, PI-regulators installed in parts of both contours of the current parameter vector (torque current and magnetization current) described by the equations in the synchronous basis related to the rotor flux coupling parameter are most widely used as current parameter regulators.

In closed current circuits with PI-controllers, it is necessary to find a compromise between speed response, accuracy on the one hand, and overshoot on the other, with the result that the speed of current circuits is limited. Uncertainties of the control object significantly degrade the dynamic characteristics of current circuits with PI controllers. In addition, non-linear cross-links exist between the current circuits. In systems with PIregulators, to eliminate the effect of cross-links, it is necessary to introduce compensating non-linear crosslinks that impede the control algorithm. In [10], a new principle of current loop control was proposed and investigated, which is used by CCC, which provide independent optimization of speed and accuracy on the one hand, and overshoot on the other hand, in conditions of uncertainty parameters of control objects in the presence of uncertain crosslinks.

The control objects in a synchronous basis with a sufficient degree of accuracy for this task can be described by an amplifying link with an unknown gain koeficient $k_{l}$. The effect of unknown causes of changes in voltage parameters, the voltage drop across the transistors of FC, the delay in their opening and closing, as well as the effect of "dead" time can be taken into account by the deviation of $k_{l}$ from its nominal value. As shown in [10], analog filters with compensators will well eliminate noise caused by PWM and do not distort the phases and amplitudes of the main harmonics. This means that when considering processes in a synchronous basis, the influence of filters will manifest itself only in the form of noise suppression. The operation of the control object in 
the synchronous basis is described by the following nonlinear system of equations [11]:

$$
\begin{gathered}
T_{r} p \psi_{d}=-\psi_{d}+L_{m} i_{d}, \\
\sigma L_{s} p i_{d q}=-R_{s} i_{d q}-\omega_{0} \sigma L_{s} J i_{d q}-e_{d q}+u, \\
e=\omega_{0} L_{m r} J \psi+L_{m r} p \psi, \\
u=k_{1} u_{d q} p, \\
T_{r}=\frac{L_{r}}{R_{r}}, \sigma=1-\frac{L_{m}^{2}}{L_{s} L_{r}}, L_{m r}=\frac{L_{m}}{L_{r}}, T_{s}^{\prime}=\sigma \frac{L_{s}}{R_{S}}, \\
\psi=\left[\begin{array}{c}
\psi_{d} \\
0
\end{array}\right], i=i_{d q}=\left[\begin{array}{l}
i_{d} \\
i_{q}
\end{array}\right], u=u_{d q}=\left[\begin{array}{l}
u_{d} \\
u_{q}
\end{array}\right], \\
e=e_{d q}=\left[\begin{array}{c}
e_{d} \\
e_{q}
\end{array}\right], J=\left[\begin{array}{cc}
0-1 \\
1 & 0
\end{array}\right] .
\end{gathered}
$$

Since $T_{r} \gg T_{S}^{\prime}$, then in (20), (21) we can assume $\psi=$ const . Each matrix equation (19)-(22) corresponds to two scalar equations. Due to the skew-symmetric matrix $J$ between these equations, there are cross-links that degrade the dynamics and complicate the synthesis of the control system. The resistances $R_{s}$ and $R_{r}$, and, consequently, $T_{s}^{\prime}$ and $T_{r}$ as a result of a change in the temperature parameter of the control object can significantly change and assume unknown values, significantly influencing the dynamics of the contours. The components in equations (20), (21), proportional to $J$, make these equations nonlinear. System (19)-(22) does not take into account the influence of nonlinear blocks 2 and 8 for two reasons: 1) these blocks are described by algebraic equations, which do not give a delay for sufficiently small counting cycles, 2) possible inaccuracies of calculations in these blocks will be part of uncertainties and compensated with them.

\section{EXPERIMENTS}

In [11], a robust per-channel decomposed control system was synthesized, which has a large response rate compared to the system with PI-controllers in the absence of overshoot.

Let be $R_{s 0}, k_{10}, L_{s 0}-$ nominal values of the corresponding parameters, and

$$
R_{s}-R_{s 0}=R_{s \delta}, k_{1}-k_{10}=k_{1 \delta}, L_{s}-L_{s 0}=L_{s \delta} .
$$

Following the works [8, 11], system (19)-(23) is represented as a nominal model, on which the uncertainty vector $f_{i}$ acts, namely,

$$
\begin{gathered}
p i=-\frac{1}{T_{s 0}^{\prime}} i+k_{0}\left(u_{p}+f_{i}\right), \\
k_{0}=k_{10}\left(\sigma L_{s 0}\right)^{-1}, \\
f_{i}=k_{10}^{-1}\left(k_{1 \delta} u_{p}-e-\omega_{0} \sigma L_{s} J i-R_{s \delta} i-p i L_{s \delta}\right) .
\end{gathered}
$$

All coefficients and variables in (25), (26) with the exception of $p i$ and $f_{i}$ are considered known.

CKulanina Y. V., Yarymbash D. S., Kotsur M. I., Yarymbash S. T., 2019 DOI 10.15588/1607-3274-2019-2-20
The task is to clean the signal $i$ from the ripples remaining after filtering due to PWM, estimate $f_{i}$ and compensate it in the controller. The scalar equations corresponding to the vector equation (25) are interconnected through $f_{i}$. When compensating, the equations will be solved and the uncertainties will not affect the dynamics of the contours. An independent control is built for each current loop. Therefore, in the following, we will consider scalar equations for the parameters of the magnetization current and the moment current, which coincide in form with (25), namely,

$$
p i=-\left(T_{s 0}^{\prime}\right)^{-1} i+k_{0}\left(u_{p}+f_{i}\right)
$$

with measurement

$$
y=i .
$$

The observer for evaluating $i$ and $f_{i}$ is

$$
\begin{gathered}
p \hat{i}=-\left(T_{s 0}^{\prime}\right)^{-1} \hat{i}+k_{0}\left(u_{p}+\hat{f}_{i}\right)+l_{1}(\hat{i}-i) \\
p \hat{f}_{i}=l_{2}(\hat{i}-i)
\end{gathered}
$$

System (30), (31) is linear with constant coefficients, the speed of which can be set by any.

The combined current loop controller will be presented in the form

$$
u_{p}=k_{0}^{-1} p i_{p}+\left(k_{0} T_{s 0}^{\prime}\right)^{-1} i_{p}-\left(q_{1}+q_{2} p^{-1}\right)\left(\hat{i}-i_{p}\right)-\hat{f}_{i}
$$

Note. The integral part in the regulator (32) is intended only for the formation of the desired type of transient response. The astatism of the system is provided by the compensating part $f_{i}$.

Substituting (32) into (28) with regard to the relations

$$
\hat{i}=i+\tilde{i}, \hat{f}_{i}=f_{i}+\tilde{f}_{i},
$$

gives the dynamics equations of the controlled current loop

$p\left(i-i_{p}\right)=-\left(T_{s 0}^{\prime}\right)^{-1}\left(i-i_{p}\right)-k_{0}\left[\left(q_{1}+q_{2} p^{-1}\right)\left(i-i_{p}+\tilde{i}\right)-\tilde{f}_{i}\right]$.

With the right choice of observer parameters, the variables $\tilde{i}, \tilde{f}_{i}$ tend to zero over time. In this case, the equation of dynamics and current regulators take the form

$$
\begin{gathered}
p\left(i-i_{p}\right)=-\left[\left(T_{s 0}^{\prime}\right)^{-1}+k_{0}\left(q_{1}+q_{2} p^{-1}\right)\right]\left(i-i_{p}\right), \\
u_{p}=k_{0}^{-1} p i_{p}+\left(k_{0} T_{s 0}^{\prime}\right)^{-1} i_{p}-\left(q_{1}+q_{2} p^{-1}\right)\left(i-i_{p}\right) .
\end{gathered}
$$

Under the simplified control law and the exact work of the observer, analogous equations will have the form

$$
\begin{gathered}
p i=-\left[\left(T_{s 0}^{\prime}\right)^{-1}+k_{0} q_{1}\right]\left(i-i_{p}\right), \\
u_{p}=\left(k_{0} T_{s 0}^{\prime}\right)^{-1} i_{p}-q_{1}\left(i-i_{p}\right) .
\end{gathered}
$$


In the full system, taking into account the dynamics of the observer and the controller, equations (35), (37) are used to select controller parameters. In the developed linear system, these equations will describe the operation of the current loop. The transfer function of the complete system (35) is equal to one, the simplified system is

$$
W(p)=\frac{i}{i_{p}}=\frac{\left(T_{s 0}^{\prime}\right)^{-1}+k_{0} q_{1}}{p+\left[\left(T_{s 0}^{\prime}\right)^{-1}+k_{0} q_{1}\right]} .
$$

Attention should be paid to the fact that the operation of the current circuits does not depend on the imperfections included in the uncertainty vector (27), namely:

1) a sharp change in the voltage parameters of the supply network;

2) all errors of the frequency converter (resistances of keys, delays in their opening and closing, dead time);

3) cross-connections between the parameters of the torque and magnetizing current contours;

4) changes in parameters (including temperature) resistances of the circuits

5) changes in the parameters of the circuits inductances, due to the non-linearity of the control object.

As shown by the numerical simulation of a complete non-linear model of current loop control systems as part of $\mathrm{VC}$, taking into account the worst combination of uncertainties [8], models (35) and (37) reproduce the control process in both loops with high accuracy, ensuring the time of the transition process current parameters $i_{d p}$, $i_{q p}$, which does not exceed 0.001-0.003 s. (Transition time can be set and guaranteed in advance).

From the expression (6) follows: the nominal parameter of the electromagnetic moment $m_{0}$ is proportional to the product $i_{d} i_{q}$. To eliminate this nonlinearity, it is customary to fix the values of the magnetizing current parameter by setting $i_{d p}=$ const, as a result of which the torque program parameter of the current is determined by expression (18). Based on the above, $i_{d}=i_{d p}=$ const will be relied upon. In a simplified system, which provides for the ideal work of observers of uncertainties and their compensation, equation (35), (37) describe the operation of a closed loop of current.

With positional control, the displacement, by which the velocity can be calculated, is measured or calculated on a mandatory basis. In this case, the same method can be used to estimate the speed, both in the original nonlinear and in the equivalent linear system. The problem occurs when controlling speed in the absence of information about speed and movement. In the monograph [11], several methods for estimating velocities are considered.

Unfortunately, among the known methods, no methods were found that could be used in the developed equivalent linear system. Therefore, in a linear system, the velocity will be considered known. In this regard, there is no need to estimate the parameters of the stator and rotor resistances. Therefore, the following are methods for estimating velocities and resistances used in the original nonlinear system.

In a complete (non-linear) system, the synchronous speed parameter is estimated from the dependence [11]

$$
\hat{\omega}_{\mathrm{o}}=\frac{\hat{\psi}_{\alpha} e_{\beta}-\hat{\psi}_{\beta} e_{\alpha}}{\hat{\psi}_{\alpha}^{2}+\hat{\psi}_{\beta}^{2}} \text {. }
$$

The estimation of the flux linkage parameter is performed with the help of an observer recorded in a vector form in a winding basis [11]

$$
\begin{gathered}
p \hat{\psi}=e_{0}+\hat{e}_{\delta}+l_{1}\left(\hat{\psi}-\psi^{*}\right), \\
p \hat{e}_{\delta}=l_{2}\left(\hat{\psi}-\psi^{*}\right) .
\end{gathered}
$$

The rotor speed parameter is determined by the expression

$$
\begin{gathered}
\omega=\frac{\omega_{0}-\omega_{s l}}{n}, \\
\omega_{s l}=\frac{i_{q}}{T_{r} i_{d p}}=\frac{R_{r} i_{q}}{L_{r} i_{d p}} .
\end{gathered}
$$

The stator resistance parameter is estimated using an observer with a transfer coefficient $l_{s}[8]$

$$
\begin{gathered}
\dot{z}_{s}=l_{s}\left[\left|i_{d q p}\right|^{2}\left(z_{s}+l_{s} \frac{1}{2} \sigma L_{s}\left|i_{d q p}\right|^{2}\right)-i_{d q p}^{T} u_{d q}+R_{s 0}\left|i_{d q p}\right|^{2}+\omega_{0} \frac{m_{0}}{n}\right], \\
\hat{R}_{S \delta}=z_{S}+l_{s} \frac{1}{2} \sigma L_{S}\left|i_{d q p}\right|^{2} \\
R_{S}=R_{S 0}+\hat{R}_{S \delta} .
\end{gathered}
$$

To estimate the rotor resistance parameter, we will use its connection with the stator resistance parameter, due to the interrelation of the rotor and stator temperature parameters, as indicated in [8].

$$
\hat{R}_{r}=R_{r 0}\left(\hat{R}_{s} R_{s 0}^{-1}\right) .
$$

In the proposed $\mathrm{VC}$ system, the present parameter of rotor resistance is included only in expression (45). Estimation of the temperature of the stator $T_{t s}$ and the rotor $T_{t r}$ can be done by dependencies

$$
\hat{T}_{t s}=T_{0}+\left(\hat{R}_{s} R_{s 0}^{-1}-1\right) \alpha^{-1}, \hat{T}_{t r}=\hat{T}_{t s} .
$$

Fig. 4 shows a block diagram of a linearized system of VC IM, which consists of the circuit of the torque current and the dynamics of the mechanical part of the system.

Block 3 (Fig. 4) takes into account the limitations of the current parameter in the original system. The element in the feedback takes into account the possible time lag that occurs when estimating the speed in the original nonlinear system. The transfer function of the inertial link in a straight chain is equal to the function in (39). As can be seen in the figure 4 , the block diagram of the linearized system VC IM is simpler than the block diagram of a DC motor of independent excitation (there is no EMF circuit). 


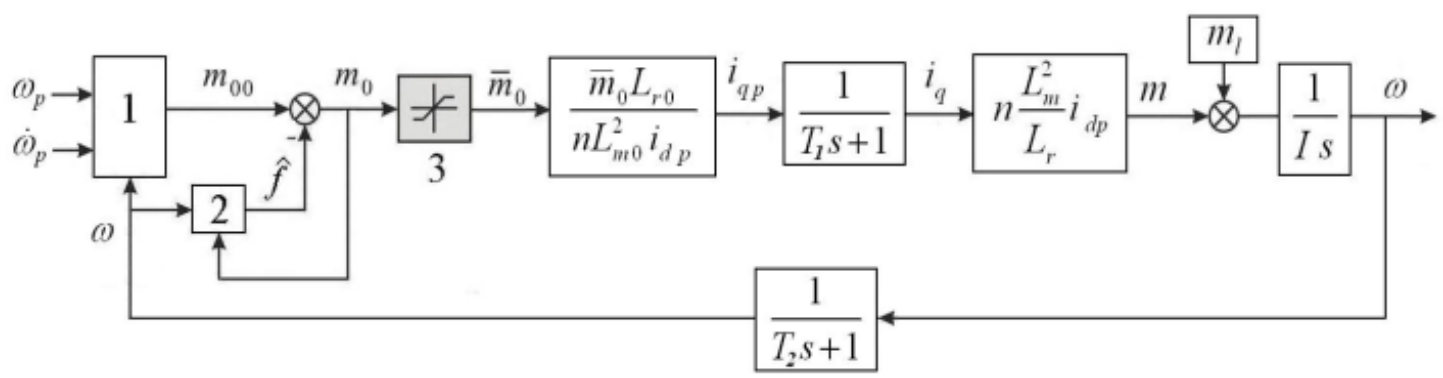

Figure 4 - Block diagram of the linearized system VC AD:

1 - block forming the type of transition characteristics $m_{00}(14), 2$ - block forming of uncertainty observer $\hat{f}_{m}(9), 3-$ limiting block of electromagnetic moment parameter value $m_{0}$,

The linearization of the original nonlinear indefinite system was carried out by applying robust control methods that compensate for uncertainties. Therefore, all the parameters of the scheme, except for the given moment of rotor inertia and the load, are reliably known and are set in advance.

A simulation of a complete non-linear system of equations was carried out, which corresponds to Fig. 2, and the linear system of equations, corresponds to Fig. 4 using the graphic extension package MATLAB for system SimuLink. At achievement of steady speeds the load was put and removed. At positive speeds, IM worked in the motor mode, and at negative speeds - in the generator mode.

\section{RESULTS}

In Fig. 5-11, the processes obtained by simulating a complete non-linear system of equations (index $n$ ) and a linear system of equations (index $l$ ) are compared. As seen in Fig. 5 and Fig. 6, in all modes of operation: acceleration, stabilization of speed under load in the motor and generator modes and without load, reverse and stabilization of zero speed, the vector control system provides good tracking of a given trajectory. Fig. 7 shows the change in the parameters of the magnetizing and moment currents during the operation cyclogram corresponding to Fig. 5. Fig. 8 illustrates the zero-speed stabilization process with no load and under load from $0.25 \mathrm{~s}$. to 3 seconds. At the time point of $1.25 \mathrm{~s}$, the voltage dropped by $30 \%$, and by 2 s. tension recovered. In Fig. 9 shows a fragment of the process shown in Fig. 8.

As follows from Fig. 5-9, overload, load shedding, failure and recovery of voltage only briefly violate the stabilization of a given speed. The system is astatic with respect to the specified actions. All of the above applies to the original nonlinear system. The linear model, operating independently, reproduces with high accuracy the change in both currents and speeds at all points in time, except for moments of voltage sudden change.

The above confirms the ability to develop algorithms for vector management of IM with a nonlinear model, working with a linear model. Herewith you can use welldesigned simple linear methods. Modeling processes using a linear model requires an order of magnitude less time than modeling a complete model. To predict the behavior of the nonlinear system when the reduced moment of rotor inertia changes in Fig. 10 and 11, 3 simultaneously simulated processes are shown: with nominal moment of inertia (curves with index 1), 2 times larger (curves with index 2) and 2 times smaller (curves with index 3 ). The simulation results of the linear system indicate the robustness of the nonlinear system with respect to the change in the reduced moment of IM rotor inertia.

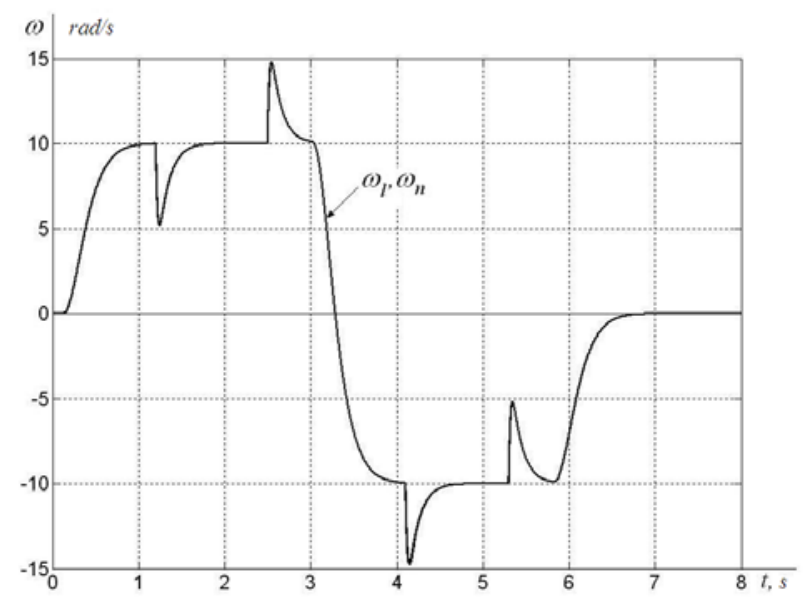

Figure 5 - Engine Speed

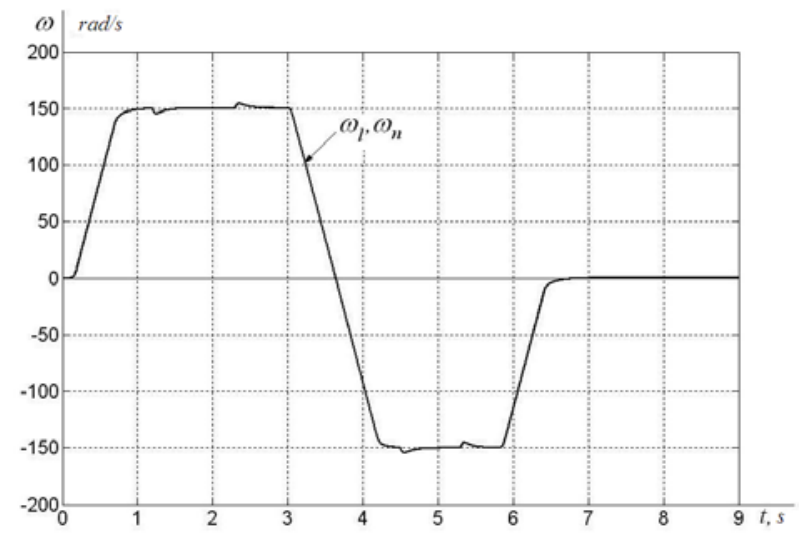

Figure 6 - Engine speed at acceleration up to $150 \mathrm{rad} / \mathrm{s}$ 


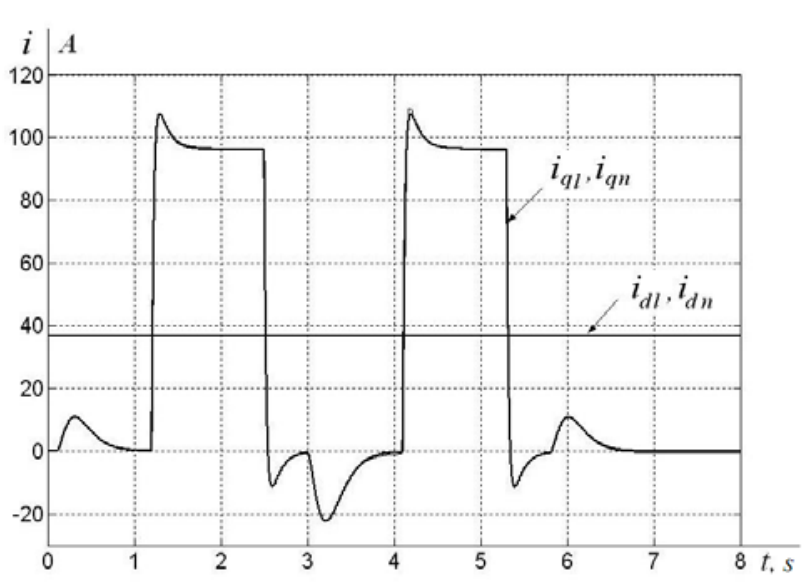

Figure 7 - Magnetizing and torque currents

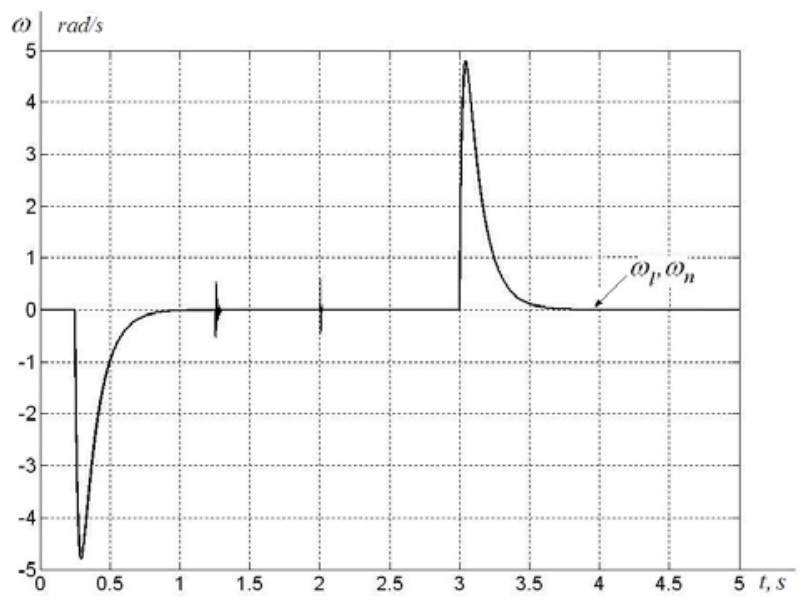

Figure 8 - Zero speed stabilization

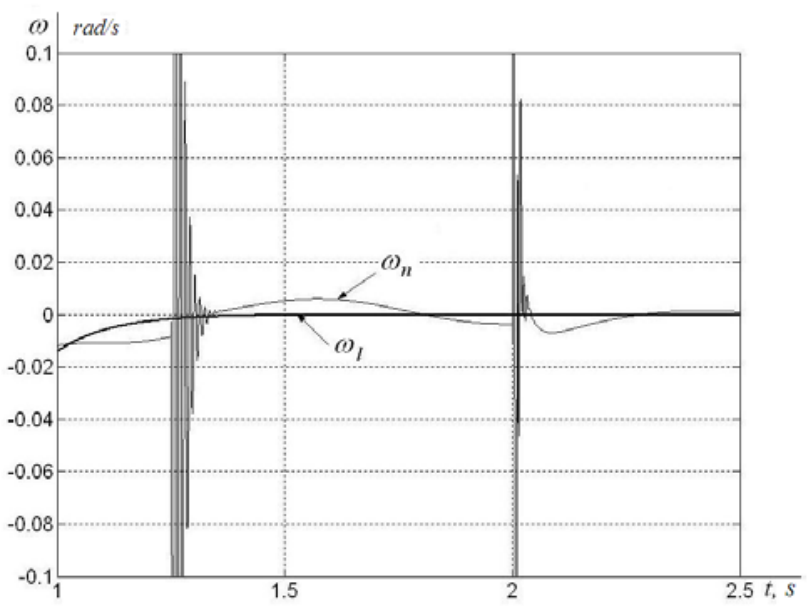

Figure 9 - System reaction at the voltage drop at zero-velocity stabilization

\section{DISCUSSION}

For the system of VC AD with a non-linear mathematical model, a simple equivalent mathematical model is compiled that describes the operation of the initial system in all operating modes quite accurately. The equivalent system preserves the robustness of the original system with respect to the inaccuracy of knowing the parameters of the reduced

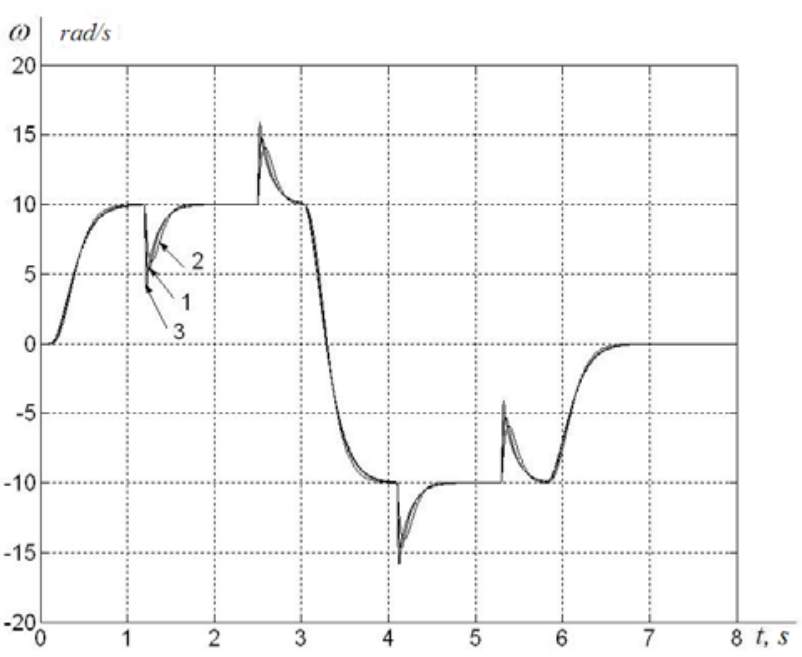

Figure 10 - Motor speed at various moments of inertia

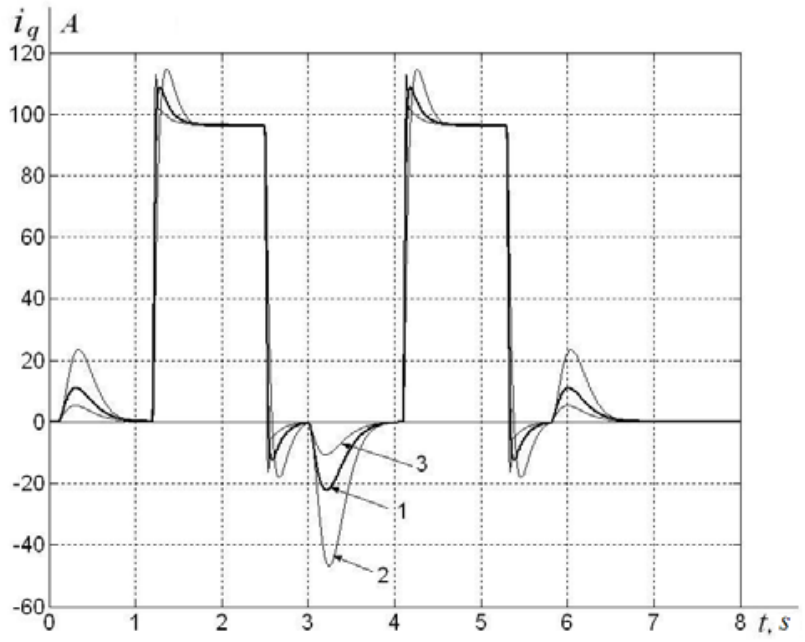

Figure 11 - Magnetizing motor currents at different moments of inertia

moment of rotor inertia, load, friction, resistance of the stator and rotor, inaccuracy formation of the electromagnetic moment, voltage spikes, all errors of the frequency converter (resistances of keys, delays of their opening and closing, dead time, nonlinearity of the equivalent characteristic), cross-links between the torque and magnetizing circuits of the current.

The simplicity and linearity of the equivalent system allows us to synthesize the control laws of the original nonlinear system by well-developed linear methods with significantly less time spent on modeling. This is especially important when developing control systems for complex dynamic objects using induction motors. Numerical simulation of the dynamics of the original nonlinear and equivalent linear systems showed a good agreement between transient and stationary processes. Developed linear control methods with small modifications can be applied to control using DC motors and synchronous motors. 


\section{CONCLUSIONS}

1. The scientific novelty of obtained results:

- for the robust system under study of vector control of an object with a substantial non-linearity of properties and characteristics, simple equivalent models were compiled that fairly accurately reproduce the operation of the original system in all modes of operation. Simplification of models is achieved by considering the dynamics of the entire system in a synchronous basis, robust methods of controlling the parameters of currents and by neglecting really small errors in the work of regulators and observers of current circuit;

- synthesized models, as well as the original nonlinear system, have the property of robustness due to the use of combined control, as the whole drive, and current circuits. Due to this, equivalent systems, as well as the original, retain the robustness property in relation to

- inaccuracies of parameters knowledge of the given moment of rotor inertia, load, friction;

- inaccuracies in the formation of the electromagnetic moment;

- to all errors of the frequency converter (resistances of keys, lateness of their opening and closing, dead time);

- cross-connections between the torque and magnetizing circuits of currents;

- changes (including temperature) resistance contours;

- changes in the inductance of the circuits, due to the magnetization curve;

- power surges.

2. The practical significance of obtained results.

The simplicity and linearity of the equivalent system allows us to synthesize the control laws of the original nonlinear system by well-developed linear methods with significantly less time spent on modeling. The obtained results confirm that the linearized vector-controlled object model can be used to control of IM.

\section{ACKNOWLEDGEMENTS}

The studies outlined in the article were carried out on the basis of Zaporizhzhya National Technical University in accordance with the thematic research plan for the state budget theme DB 03517 "Raise the efficiency and reliability of electrical systems transformation of alternating current" (state registration number 0117U003921).

\section{REFERENCES}

1. Khalil H.J. Nonlinear systems. N.-J. Prentice Hall, 1996, 750 p.

2. Isidori A. Nonlinear control systems. N.-Y. Springer, 1995, 657 p.

3. Yarymbash D. S., Yarymbash S. T., Kotsur M. I., Litvinov D. O. Computer simulation of electromagnetic field with application the frequency adaptation method, Radio Electronics, Computer Science, Control, 2018, No. 1, pp. 65-74. DOI: https://doi.org/10.15588/1607-3274-2018-1-8.

4. Yelkin V.I. O redukcii nelineunyh upravljaemyh system k lineynym, Avtomatika i telemehanika, 2000, No. 2, pp. 45-55.

5. Nikiforov V.O. Adaptivnoe i robastnoe upravlenie s kompencaciey vozmusheniy. SPb.,Nauka, 2003, 282 p.

6. Salleh Z., Sulaiman M., Omar R. Optimization of Fuzzy Logic Based for Vector Control Induction Motor Drives, IEEE 8th Computer Science and Electronic Engineering (CEEC), UK, 28-30 September 2016: proceedings, Colchester, IEEE, 2016, pp. 83-86. DOI: 10.1109/CEEC.2016.7835893.

CKulanina Y. V., Yarymbash D. S., Kotsur M. I., Yarymbash S. T., 2019 DOI 10.15588/1607-3274-2019-2-20
7. Patakor F. A., Salleh Z., Sulaiman M., Jantan N. Auto-tuning Sliding Mode Control for Induction Motor Drives, IEEE 8th Computer Science and Electronic Engineering (CEEC), UK, 28-30 September 2016: proceedings. Colchester, IEEE, 2016, pp. 1-6. DOI: 10.1109/CEEC.2016.7835892.

8. Raumer T. V., Dion J. M., Dugard L. Applied nonlinear control of an induction motor using digital signal processing, IEEE Trans. Control System Technology, 1994. Vol. 2, No. 4, pp. 327-335. DOI: https://doi.org/10.1002/acs.4480070511.

9. Kuroe Y., Yoneda Y. Design of a new controller for induction motors based on exact linearization, Industrial Electronics, Control and Instrumentation, Japan, 28 October-1 November 1991: proceedings. Kobe, IECON, 1991, Vol. 1, pp. 621-626. DOI: 10.1109/IECON.1991.239215.

10. Blaschke F. Das Prinzip der Feldorientiening die Grundlage fur die Transvector - Regelung von Asynchronmaschienen. SiemensZeitschrift, 1971, 757 p.

11. Potapenko Y. M., Potapenko Y. Y. Robastnye algoritmy vectornogo upravlenija asinhronnym privodom. Zaporizhzhya, ZNTU, 2009, $352 \mathrm{p}$.

12. Karnauhov N. F. Electromehanicheskie i mehatronnye sistemy. Rostov-na-Donu, Feniks, 2006, 320 p.

13. Karnauhov N. F. Impulsnye preobrazovayeli ispolnitelnyh ustroystv electromehatronnyh sistem, Uchebnoe posobie. Rostovna-Donu, DGTU, 1994, $71 \mathrm{p}$.

14. Peresada S., Tilli A., Tonielli A. New passivity based speedfluxtracking controllers for induction motor, Annual Conference of the IEEE Industrial Electronics Society, Japan, 22-28 October 2000: proceedings. Nagoya, IECON, 2000, Vol. 2, pp. 1099-1104. DOI: 10.1109/IECON.2000.972276.

15. Peresada S., Tilli A., Tonielli A. Theoretical and Experimental Comparison of indirect field-oriented Controllers for Induction Motors, IEEE Transactions On Power Electronics, 2003, Vol. 18, No. 1, pp. 151-163. DOI: 10.1109/TPEL.2002.807123.

16. Peresada S., Kovbasa S., Dymko S. Indirect Field-Oriented Torque Control of Induction Motors with Maximum Torque per Ampere Ratio, Transactions of Kremenchuk State University, 2010, Vol. 2, No. 3 , pp. $33-36$.

17. Wasynchuk O., Sudhoff S. D., Corsine K. A., Tichenor J. et al. A Maximum Torque per Ampere Control Strategy for Induction Motor Drives, IEEE Transactions on Energy Conversion, 1998, Vol. 13, No. 2, pp. 163-169. DOI 10.1109/60.678980.

18. Grcar B., Cafuta P., Stumberger G. et al. Non-Holonomy in Induction Machine Torque Control, IEEE Transactions on Control Systems Technology, 2011, Vol. 19, No. 2, pp. 367-375. DOI: 10.1109/TCST.2010.2042718.

19. Famouri P., Cathey J. J. Loss Minimization Control of an Induction Motor Drive, IEEE Transactions Industrial Applicaions, 1991, Vol. 27, pp. 32-37. DOI: 10.1109/28.67529

20. Dymko S., Peresada S., Leidhold R. Torque Control of Saturated Induction Motor with Torque per Ampere Ratio Maximization, IEEE International Conference on Intelligent Energy and Power Systems, Ukraine, 2-6 June 2014: proceedings. Kiev, IEPS, 2014, pp. 251-256. DOI: 10.1109/IEPS.2014.6874189.

21. Kwon C., Sudhoff S. D. An Improved Maximum Torque per amp Control Strategy for Induction Machine Drives, IEEE Applied Power Electronics Conference and Exposition, USA, 6-10 March 2005, proceedings. Austin, APEC, 2005, Vol. 2, pp. 740-745. DOI: 10.1109/APEC.2005.1453052.

22. Marino R., Peresada S., Valigi P. Adaptive input-output linearizing control of induction motors, IEEE Transactions on Automatic Control, 1993, Vol. 38, № 2, pp. 208-221. DOI:10.1109/9.250510.

23. Peresada S., Kovbasa S., Korol S., Zhelinskyi N. Feedback linearizing field-oriented control of induction generator: Theory and experiments, Tekhnichna Elektrodynamika, 2017, No. 2017, Issue 2, pp. $48-56$.

24. Ambrish D., Madhusudan S., Narendra K. DSP based feedback linearization control of vector controlled induction motor drive, IEEE International Conferenceon Power Electronics, Intelligent Controland Energy Systems, India 4-6 July 2016, proceedings. Delhi, ICPEICES, 2016, pp. 36-42. DOI: 10.1109/ICPEICES.2016.7853631.

25. Sobczuk D. L. Feedback Linearization Control of Inverter Fed Induction Motor-DSP Implementation, IEEE International 
Symposium on Industrial Electronics, Italy, 8-11 July 2002: proceedings. L'Aquila, IEEE, 2002, pp. 678-682. DOI: 10.1109/ISIE.2002.1026373.

26. Sobczuk D., Malinowski M. Feedback linearization control of inverter fed induction motor with sliding mode speed and flux observers, Annual Conference on IEEE Industrial Electronics,
France, 6-10 November 2006: proceedings. Paris, IEEE, 2006, Vol. 2, No. 5, pp. 1299-1304. DOI: 10.1109/IECON.2006.348089.

27. Marquez H. J. Nonlinear control systems. New Jersey, John Wiley \& Sons, 2003, 376 p.

\section{УДК 681.527 .2}

Куланіна Є. В. - канд. техн. наук, старший викладач кафедри електричних машин Запорізького національного технічного університету, Запоріжжя, Україна.

Яримбаш Д. С. - д-р техн. наук, доцент, завідувач кафедри електричних машин Запорізького національного технічного університету, Запоріжжя, Україна.

Коцур М. І. - канд. техн. наук, доцент кафедри електричних електронних апаратів Запорізького національного технічного університету, Запоріжжя, Україна.

Яримбаш С. Т. - канд. техн. наук, доцент кафедри електричних машин Запорізького національного технічного університету, Запоріжжя, Україна.

Актуальність. Достатня кількість способів реалізації алгоритмів векторного керування є дуже складними та у більшості випадків мають схильність до незбіжності вектору результуючих параметрів об'єкту керування. Тому існує потреба у спрощенні складних нелінійних системи векторного керування та застосування для них лінійних динамічних моделей нелінійного об'єкта з векторним керуванням. В даний час для складної системи векторного керування відсутні досить точні еквівалентні прості моделі. Розробка надійних простих динамічних моделей дозволить проектувати векторну систему керування з максимальним використанням лінійних методів синтезу та аналізу.

Мета статті - розробка лінійної динамічної моделі нелінійного об'єкта 3 векторним керуванням, яка 3 достатньою для практики точністю відтворює його диніміку.

Методи дослідження. Для вирішення поставлених завдань використано такі методи: метод простору станів для опису роботи систем керування; теорія фільтрації, зокрема, спостерігачів, для оцінки векторів стану, невизначеностей та ідентифікації параметрів; методи модального керування для синтезу спостерігачів і регуляторів; метод чисельного моделювання для ілюстрації працездатності синтезованих систем керування; векторне керування нелінійним обєктом.

Результати. Для досліджуваної робастної системи векторного керування об'єктом з суттєвою нелінійністю властивостей та характеристик складені прості лінійні еквівалентні математичні моделі, що досить точно відтворюють роботу вихідної системи у всіх режимах роботи. Спрощення математичних моделей досягається шляхом розгляду динаміки всієї системи в синхронному базисі, робастних методів керування параметрами, та за рахунок нехтування дійсно малими похибками роботи регуляторів і спостерігачів. Синтезовані моделі, так само, як і вихідна нелінійна система, мають властивість робастності за рахунок застосування комбінованого керування.

Висновки. Простота та лінійність еквівалентної системи дозволяють синтезувати закони керування вихідної нелінійної системи добре розробленими лінійними методами 3 істотно меншими витратами часу на моделювання. Чисельне моделювання динаміки вихідної нелінійної та еквівалентної лінійної систем показало добрий збіг перехідних і стаціонарних процесів.

КЛЮЧОВІ СЛОВА: модель, лінійність, керування, спостерігач, робастність.

\section{УДК 681.527.2}

\section{ЛИНЕАРИЗАЦИЯ МОДЕЛИ ОБЪЕКТА С ВЕКТОРНЫМ УПРАВЛЕНИЕМ}

Куланина Е. В. - канд. техн. наук, старший преподаватель кафедры электрических машин Запорожского национального технического университета, Запорожье, Украина.

Ярымбаш Д. С. - д-р техн. наук, доцент, заведующий кафедрой электрических машин Запорожского национального технического университета, Запорожье, Украина.

Коцур М. И. - канд. техн. наук, доцент кафедры электрических и электронных аппаратов Запорожского национального технического университета, Запорожье, Украина.

Ярымбаш С. Т. - канд. техн. наук, доцент кафедры электрических машин Запорожского национального технического университета, Запорожье, Украина.

Актуальность. При достаточном количестве способов реализации алгоритмов векторного управления, они являются очень сложными, и в большинстве случаев имеют склонность к несходимости вектора результирующих параметров объекта управления. Поэтому существует необходимость в упрощении сложных нелинейных систем векторного управления и применение для них линейных динамических моделей нелинейного объекта с векторным управлением. В настоящее время для сложной системы векторного управления отсутствуют достаточно точные эквивалентные простые модели. Разработка надежных простых динамических моделей позволит проектировать векторную систему управления с максимальным использованием линейных методов синтеза и анализа.

Цель статьи. Разработка линейной динамической модели нелинейного объекта с векторным управлением, которая с достаточной для практики точностью воспроизводит его динимику.

Методы исследования. Для решения поставленных задач использованы следующие методы: метод пространства состояний для описания работы систем управления; теория фильтрации, в частности, наблюдателей, для оценки векторов состояния, неопределенностей и идентификации параметров; методы модального управления для синтеза наблюдателей и 
регуляторов; метод численного моделирования для иллюстрации работоспособности синтезированных систем управления; векторное управление нелинейным объектом.

Результаты. Для исследуемой робастной системы векторного управления объектом с суттювою нелинейностью свойств и характеристик составлены простые линейные эквивалентные математические модели, которые достаточно точно воспроизводят работу исходной системы во всех режимах работы. Упрощение математических моделей достигается путем рассмотрения динамики всей системы в синхронном базисе, робастных методов управления параметрами, и за счет пренебрежения действительно малыми погрешностями работы регуляторов и наблюдателей. Синтезированные модели, так же, как и исходная нелинейная система, имеют свойство робастности за счет применения комбинированного управления.

Выводы. Простота и линейность эквивалентной системы позволяют синтезировать законы управления исходной нелинейной системы хорошо разработанными линейными методами с существенно меньшими затратами времени на моделирование. Численное моделирование динамики исходной нелинейной и эквивалентной линейной систем показало хорошее совпадение переходных и стационарных процессов.

КЛЮЧЕВЫЕ СЛОВА: модель, линейность, управление, наблюдатель, робастность.

\section{ЛІТЕРАТУРА / ЛИТЕРАТУРА}

1. Khalil H. J. Nonlinear systems / H. J. Khalil. - N.-J. : Prentice Hall, 1996. $-750 \mathrm{p}$.

2. Isidori A. Nonlinear control systems / A. Isidori. - N.-Y. : Springer, 1995. $-657 \mathrm{p}$

3. Computer simulation of electromagnetic field with application the frequency adaptation method / [D. S. Yarymbash, S. T. Yarymbash, M. I. Kotsur, D. O. Litvinov] // Radio Electronics, Compute Science, Control. - 2018. - № 1. - P. 65-74. DOI: https://doi.org/10.15588/1607-3274-2018-1-8.

4. Елкин В.И. О редукции нелинейных управляемых систем к линейным / В.И. Елкин // Автоматика и телемеханика. - 2000. № 2. - C. $45-55$.

5. Никифоров В.О. Адаптивное и робастное управление с компенсацией возмущений / В. О. Никифоров. - СПб. : Наука, 2003. -282 c.

6. Salleh Z. Optimization of Fuzzy Logic Based for Vector Control Induction Motor Drives / Z. Salleh, M. Sulaiman, R. Omar // IEEE 8th Computer Science and Electronic Engineering (CEEC), UK, 28-30 September 2016: proceedings. - Colchester: IEEE, 2016. P. 83-86. DOI: 10.1109/CEEC.2016.7835893.

7. Auto-tuning Sliding Mode Control for Induction Motor Drives [F. A. Patakor, Z. Salleh, M. Sulaiman, N. Jantan] // IEEE 8th Computer Science and Electronic Engineering (CEEC), UK, 28-30 September 2016: proceedings. - Colchester: IEEE, 2016. - P. 1-6. DOI: $10.1109 /$ CEEC.2016.7835892.

8. Raumer T. V. Applied nonlinear control of an induction motor using digital signal processing / T. Von Raumer, J. M. Dion, L. Dugard // IEEE Trans. Control System Technology. - 1994. - Vol. 2, № 4. P. 327-335. DOI: https://doi.org/10.1002/acs.4480070511.

9. Kuroe Y. Design of a new controller for induction motors based on exact linearization / Y. Kuroe, Y. Yoneda // Industrial Electronics, Control and Instrumentation, Japan, 28 October-1 November 1991 proceedings. - Kobe: IECON, 1991. - Vol. 1. - P. 621-626. DOI: 10.1109/IECON.1991.239215.

10. Blaschke F. Das Prinzip der Feldorientiening die Grundlage fur die Transvector - Regelung von Asynchronmaschienen / F. Blaschke. Siemens-Zeitschrift, 1971. - $757 \mathrm{p}$

11. Потапенко Е. М. Робастные алгоритмы векторного управления асинхронным приводом / Е. М. Потапенко, Е. Е. Потапенко. Запорожье : ЗНТУ, 2009. - $352 \mathrm{c}$

12. Карнаухов Н. Ф. Электромеханические и мехатронные системы / Н. Ф. Карнаухов. - Ростов-на-Дону : Феникс, 2006. - 320 с.

13. Карнаухов Н. Ф. Импульсные преобразователи исполнительных устройств электромеханотронных систем: Учеб. пособие / Н. Ф. Карнаухов. - Ростов-на-Дону : ДГТУ, 1994. $-71 \mathrm{c}$.

14. Peresada S. New passivity based speed-fluxtracking controllers for induction motor / S. Peresada, A. Tilli, A. Tonielli // Annual Conference of the IEEE Industrial Electronics Society, Japan, 22-28 October 2000: proceedings. - Nagoya: IECON, 2000. - Vol. 2. P. 1099-1104. DOI: 10.1109/IECON.2000.972276.

15. Peresada S. Theoretical and Experimental Comparison of indirect field-oriented Controllers for Induction Motors / S. Peresada, A. Tilli, A. Tonielli // IEEE Transactions On Power Electronics. -
2003 - Vol. 18, No. 1. - P 151-163. DOI: 10.1109/TPEL.2002.807123.

16. Peresada S. Indirect Field-Oriented Torque Control of Induction Motors with Maximum Torque per Ampere Ratio / S. Peresada, S. Kovbasa, S. Dymko // Transactions of Kremenchuk State University. - 2010. - Vol. 2, No. 3. - P. 33 - 36

17. A Maximum Torque per Ampere Control Strategy for Induction Motor Drives / [O. Wasynchuk, S. D. Sudhoff, K. A. Corsine, J. Tichenor et al.] // IEEE Transactions on Energy Conversion. 1998. - Vol. 13, No. 2. - P. 163-169. DOI 10.1109/60.678980.

18. Non-Holonomy in Induction Machine Torque Control / [B. Grcar, P. Cafuta, G. Stumberger et al.] // IEEE Transactions on Contro Systems Technology. - 2011. - Vol. 19, No. 2. - P. 367-375. DOI: 10.1109/TCST.2010.2042718.

19. Famouri P. Loss Minimization Control of an Induction Motor Drive / P. Famouri, J. J. Cathey // IEEE Transactions Industrial Applicaions. - 1991. - Vol. 27. - P. 32-37. DOI: 10.1109/28.67529

20. Dymko S. Torque Control of Saturated Induction Motor with Torque per Ampere Ratio Maximization / S. Dymko, S. Peresada, R. Leidhold // IEEE International Conference on Intelligent Energy and Power Systems, Ukraine, 2-6 June 2014: proceedings. - Kiev: IEPS, 2014. - P. 251-256. DOI: 10.1109/IEPS.2014.6874189.

21. Kwon C. An Improved Maximum Torque per amp Control Strategy for Induction Machine Drives / C. Kwon, S. D. Sudhoff // IEEE Applied Power Electronics Conference and Exposition, USA, 6-10 March 2005: proceedings. - Austin: APEC, 2005. - Vol. 2. P. 740-745. DOI: 10.1109/APEC.2005.1453052.

22. Marino R. Adaptive input-output linearizing control of induction motors / R. Marino, S. Peresada, P. Valigi // IEEE Transactions on Automatic Control. - 1993. - Vol. 38, № 2. - P. 208-221. DOI: $10.1109 / 9.250510$

23. Feedback linearizing field-oriented control of induction generator: Theory and experiments / [S. Peresada, S. Kovbasa, S. Korol, N. Zhelinskyi] // Tekhnichna Elektrodynamika. - 2017. - No. 2017, Issue 2. - P. 48-56.

24. Ambrish D. DSP based feedback linearization control of vector controlled induction motor drive / D. Ambrish, S. Madhusudan, K. Narendra // IEEE International Conferenceon Power Electronics, Intelligent Controland Energy Systems, India 4-6 July 2016: proceedings. - Delhi: ICPEICES, 2016. - P. 36-42. DOI: 10.1109/ICPEICES.2016.7853631.

25. Sobczuk D. L. Feedback Linearization Control of Inverter Fed Induction Motor-DSP Implementation / D. L. Sobczuk // IEEE International Symposium on Industrial Electronics, Italy, 8-11 July 2002: proceedings. - L'Aquila : IEEE, 2002. - P. 678-682. DOI: $10.1109 /$ ISIE. 2002.1026373

26. Sobczuk D. Feedback linearization control of inverter fed induction motor with sliding mode speed and flux observers / D. Sobczuk, M. Malinowski // Annual Conference on IEEE Industrial Electronics, France, 6-10 November 2006: proceedings. - Paris: IEEE, 2006. - Vol. 2, No 5. - P. 1299-1304. DOI: 10.1109/IECON.2006.348089.

27. Marquez H. J. Nonlinear control systems / H. J. Marquez. - New Jersey : John Wiley \& Sons, 2003. -376 p. 